\title{
2-Benzyl-benzofurans from the tubers of Ophiopogon japonicus
}

Nguyen Hai Dang ${ }^{1 *}$, Nguyen Dinh Chung ${ }^{2,3}$, Ha Manh Tuan², Nguyen Van Thanh ${ }^{2,3}$, Nguyen Tuan Hiep ${ }^{4}$, Dongho Lee ${ }^{5}$ and Nguyen Tien Dat ${ }^{2,3^{*}}$ (D)

\begin{abstract}
Background: The overproduction of nitric oxide (NO) is known to involve in various inflammatory processes. A methanol extract of the tubers of Ophiopogon japonicus was found to strongly inhibit NO production. The present paper deals with the isolation, structural identification and NO inhibitory effect of five compounds isolated from the $\mathrm{MeOH}$ extract of $O$. japonicus tubers.

Results: Three new compounds were elucidated to be (2R)-(4-methoxybenzyl)-5,7-dimethyl-6-hydroxyl-2,3-dihydrobenzofuran (1), 2-(2-hydroxyl-4-methoxy-benzyl)-5-methyl-6-methoxyl-2,3-dihydrobenzofuran (2), and 2-(4-hydroxy-benzyl)-5,6-dihydroxybenzofuran (3). In addition, two known compounds were isolated from a natural source for the first time including 2-(4-methoxy-benzyl)-6,7-dimethoxyl-2,3-dihydrobenzofuran (4), and 2-(4-methoxybenzyl)-6,7-methylenedioxy-2,3-dihydrobenzofuran (5). The absolute configuration of compound $\mathbf{1}$ was determined by experimental and calculated circular dichroism spectra. The effects of the isolated compounds on LPS-induced NO production in RAW264.7 cells were evaluated. Compound $\mathbf{1}$ and $\mathbf{2}$ showed the inhibitory activity with $I_{50}$ values of 11.4 and $29.1 \mu \mathrm{M}$, respectively.
\end{abstract}

Conclusions: The class of 2-benzyl-2,3-dihydrobenzofuran is uncommon in nature. In this work, three such compounds were isolated from 0 . japonicus. Two of them showed promising anti-inflammatory activity by inhibition of NO production.

Keywords: Ophiopogon japonicas, Dihydrobenzofuran, 2-Benzyl-2,3-dihydroxybenzofuran, 2-Benzyl-benzofuran, Inhibition of NO production

\section{Background}

Ophiopogon japonicus (L.f) Ker-Gawl (Convallariaceae) occurs widely in Vietnam and it has been used in traditional medicine to treat cough, fever, epistaxis, inflammation, respiratory disease, constipation, and gastrointestinal disorders [1]. Steroidal saponins are among the main characteristic components of O. japonicus and have anticancer, anti-inflammatory, antioxidative, and neuritogenic effects [2-4]. Homoisoflavonoids are also

\footnotetext{
*Correspondence: nguyenhd@imbc.vast.vn; ngtiend@imbc.vast.vn ${ }^{1}$ Advanced Center for Bio-organic Chemistry, Institute of Marine Biochemistry, Vietnam Academy of Science and Technology (VAST), 18-Hoang Quoc Viet, Cau Giay, Hanoi, Vietnam

${ }^{2}$ Institute of Marine Biochemistry, Vietnam Academy of Science and Technology (VAST), 18-Hoang Quoc Viet, Cau Giay, Hanoi, Vietnam Full list of author information is available at the end of the article
}

characteristic of O. japonicus and possess anti-inflammatory, antioxidative, and cytotoxic activities [4-8]. $O$. japonicus is also rich in polysaccharides that have antidiabetic, antioxidative, anti-inflammatory, and immunomodulatory properties [4, 7]. In addition, phenolic acids, sesquiterpenes, fatty acids, and lignans have been identified from O. japonicus $[4,9,10]$.

Nitric oxide (NO) is produced by inducible nitric oxide synthase (iNOS) in macrophages, hepatocytes, and renal cells. When produced in excess, NO directly damages normal tissues and triggers inflammation. Therefore, inhibitors of NO production have potential therapeutic value as anti-inflammatory agents [11]. In our search for anti-inflammatory compounds from natural sources, a methanol $(\mathrm{MeOH})$ extract of the tubers of O. japonicus was found to strongly inhibit NO 
production. Phytochemical fractionation of the $\mathrm{CHCl}_{3}$ soluble fraction of the $\mathrm{MeOH}$ extract led to the isolation of five 2-benzyl benzofurans, including three new (1-3) and two known $(\mathbf{4}, \mathbf{5})$ compounds (Fig. 1). Compound 1 strongly inhibited NO production in lipopolysaccharide (LPS)-induced RAW264.7 cells.

\section{Results and discussion}

Compound 1 was obtained as a brown solid. Its molecular formula was determined to be $\mathrm{C}_{18} \mathrm{H}_{20} \mathrm{O}_{3}$ from highresolution electrospray ionisation mass spectrometry (HRESIMS) $\left(m / z 283.1365[\mathrm{M}-\mathrm{H}]^{-}\right)$. Its ${ }^{1} \mathrm{H}$ NMR spectrum showed the characteristic resonance of an $\mathrm{AA}^{\prime} \mathrm{BB}^{\prime}$ aromatic ring $\left[\delta_{\mathrm{H}} 7.19\left(2 \mathrm{H}, \mathrm{d}, J=8.5 \mathrm{~Hz}, \mathrm{H}-2^{\prime}, 6^{\prime}\right)\right.$, and $\left.6.86\left(2 \mathrm{H}, \mathrm{d}, J=8.5 \mathrm{~Hz}, \mathrm{H}-3^{\prime}, 5^{\prime}\right)\right]$, one aromatic singlet $\left[\delta_{\mathrm{H}}\right.$ $6.67(1 \mathrm{H}, \mathrm{s}, \mathrm{H}-4)]$, one oxygenated methine proton $\left[\delta_{\mathrm{H}}\right.$ 4.86 (partially overlapped with HDO signal, $\mathrm{H}-2$ )], one methoxyl group $\left[\delta_{\mathrm{H}} 3.78\left(3 \mathrm{H}, \mathrm{s}, 4^{\prime}-\mathrm{OMe}\right)\right]$, two methylene groups $\left[\delta_{\mathrm{H}} 3.07(1 \mathrm{H}, \mathrm{dd}, J=15.0,8.5 \mathrm{~Hz}, \mathrm{Ha}-3), 2.82\right.$ $(1 \mathrm{H}, \mathrm{dd}, J=15.0,7.5 \mathrm{~Hz}, \mathrm{Hb}-3), 3.02(1 \mathrm{H}, \mathrm{dd}, J=14.0$, $\left.\left.7.0 \mathrm{~Hz}, \mathrm{Ha}-7^{\prime}\right), 2.84\left(1 \mathrm{H}, \mathrm{dd}, J=14.0,6.5 \mathrm{~Hz}, \mathrm{Ha}-7^{\prime}\right)\right]$ and two aromatic methyl groups $\left[\delta_{\mathrm{H}} 2.12(3 \mathrm{H}, \mathrm{s}, \mathrm{Me}-5)\right.$ and 2.05 (3H, s, Me-7)] (Table 1). The ${ }^{13} \mathrm{C}$ NMR and DEPT spectra revealed the presence of two methyl carbons at $\delta_{\mathrm{C}} 9.2(7-\mathrm{Me})$ and $16.5(5-\mathrm{Me})$, two methylene carbons at $\delta_{\mathrm{C}} 35.9(\mathrm{C}-3)$ and $42.0\left(\mathrm{C}-7^{\prime}\right)$, one methoxy carbon at $\delta_{\mathrm{C}} 55.7\left(4^{\prime}-\mathrm{OMe}\right)$, one oxygenated methine carbon at $\delta_{\mathrm{C}}$ $85.1(\mathrm{C}-2)$, five methine carbons at $\delta_{\mathrm{C}} 123.9(\mathrm{C}-4), 131.4$ $\left(\mathrm{C}-2^{\prime}, 6^{\prime}\right)$, and $114.7\left(\mathrm{C}-3^{\prime}, 5^{\prime}\right)$, and seven quaternary carbons at $\delta_{\mathrm{C}} 153.8$ (C-6, observed from HMBC spectrum), 158.1 (C-7a), and 159.8 (C-4'), 118.0 (C-3a), 117.3 (C-5), $108.1(\mathrm{C}-7)$, and $131.2\left(\mathrm{C}-1^{\prime}\right)$ (Table 2). These data suggested the 2-benzyl-2,3-dihydrobenzofuran skeleton of $\mathbf{1}$
$[12,13]$. The $\mathrm{HMBC}$ correlations from aromatic singlet $\mathrm{H}-4$ to C-3, C-3a, C-5, C6, C-7a, and from Me-5 to C-4, $\mathrm{C}-5, \mathrm{C}-6$, as well as from Me-7 to C-6, C-7, C-7a indicated the presence of a dihydrobenzofuran skeleton with a hydroxyl group located at C-6 and two methyl groups located at C-5 and C-7. The methoxyl group was placed on $\mathrm{C}-4^{\prime}$ based on the HMBC correlation of the proton of this group with C-4' (Fig. 2). From these data, 1 was identified as 2-(4-methoxybenzyl)-5,7-dimethyl-6-hydroxyl-2,3-dihydrobenzofuran. The quantum chemical electronic circular dichroism (ECD) calculation method, based on time-dependent density functional theory (TDDFT), was used to determine of the absolute configuration at C-2 [14]. The predicted ECD patterns for $2 R$ were consistent with the experimentally measured ECD of 1 (Fig. 3). Thus, compound $\mathbf{1}$ was assigned as (2R)(4-methoxybenzyl)-5,7-dimethyl-6-hydroxyl-2,3-dihydrobenzofuran.

Compound 2 was obtained as a brown solid. Analysis of the HRESIMS spectrum indicated that compound 2 has molecular formula $\mathrm{C}_{18} \mathrm{H}_{20} \mathrm{O}_{4}(\mathrm{~m} / z \quad 301.1436$ $\left.[\mathrm{M}+\mathrm{H}]^{+}\right)$. The ${ }^{1} \mathrm{H}$ NMR spectrum of 2 showed the presence of two aromatic singlets $\left(\delta_{\mathrm{H}} 6.87\right.$ and 6.39), an aromatic $\mathrm{ABX}$ spin system $\left[\delta_{\mathrm{H}} 6.48(1 \mathrm{H}, \mathrm{d}, J=2.5 \mathrm{~Hz}\right.$, $\left.\mathrm{H}-3^{\prime}\right), 6.43\left(1 \mathrm{H}, \mathrm{dd}, J=8.0,2.5 \mathrm{~Hz}, \mathrm{H}-5^{\prime}\right)$, and $6.98(1 \mathrm{H}$, $\left.\left.\mathrm{d}, J=8.0 \mathrm{~Hz}, \mathrm{H}-6^{\prime}\right)\right]$, one aromatic methyl $\left(\delta_{\mathrm{H}} 2.10\right)$ and two methoxy groups $\left(\delta_{\mathrm{H}} 3.75\right.$ and 3.76$)$. The ${ }^{13} \mathrm{C}$ NMR and DEPT spectra of 2 showed the characteristics of 2-benzyl-2,3-dihydrobenzofuran, which are similar to those of 1 with one oxygenated methine carbon at $\delta_{\mathrm{C}}$ $85.8(\mathrm{C}-2)$ and two methylenes at $34.0(\mathrm{C}-3)$ and 36.9 (C-7) (Table 2). The HMBC correlations confirmed the positions of the methyl and methoxy groups (Fig. 2). In<smiles>[R]c1ccc([14CH2][14c]2[14cH]c3cc([R5])c([R])c([R])c3o2)c([R4])c1</smiles>

$\begin{array}{cccccc} & \mathrm{R}_{1} & \mathrm{R}_{2} & \mathrm{R}_{3} & \mathrm{R}_{4} & \mathrm{R}_{5} \\ \mathbf{1} & \mathrm{CH}_{3} & \mathrm{OH} & \mathrm{CH}_{3} & \mathrm{H} & \mathrm{OCH}_{3} \\ \mathbf{4} & \mathrm{CH}_{3} & \mathrm{OCH}_{3} & \mathrm{H} & \mathrm{OH} & \mathrm{OCH}_{3} \\ \mathbf{5} & \mathrm{H} & \mathrm{OCH}_{3} & \mathrm{OCH}_{3} & \mathrm{H} & \mathrm{OCH}_{3} \\ & \mathrm{H} & -\mathrm{OCH} 2 \mathrm{O}- & \mathrm{H} & \mathrm{OCH}_{3}\end{array}$<smiles>Oc1ccc(Cc2cc3cc(O)c(O)cc3o2)cc1</smiles>

Fig. 1 Structure of compounds $\mathbf{1 - 5}$ isolated from O. japonicus tubers 
Table $1{ }^{1} \mathrm{H}$ NMR data of compounds $1-5\left(\delta_{H}\right.$ in ppm, $J$ in $\left.\mathrm{Hz}\right)$

\begin{tabular}{|c|c|c|c|c|c|}
\hline Position & $1\left(\mathrm{CD}_{3} \mathrm{OD}\right)$ & $2\left(\mathrm{CDCl}_{3}\right)$ & $3\left(C_{3} \mathrm{OD}\right)$ & $4\left(\mathrm{CDCl}_{3}\right)$ & $5\left(\mathrm{CDCl}_{3}\right)$ \\
\hline 2 & 4.86, partially overlapped & $5.05, m$ & - & $5.00, m$ & $5.02, \mathrm{~m}$ \\
\hline 3 & $\begin{array}{l}\text { 3.07, dd (15.0, 8.5) } \\
2.82, \mathrm{dd}(15.0,7.5)\end{array}$ & $\begin{array}{l}3.15, \mathrm{dd}(15.0,8.5) \\
2.94, \mathrm{dd}(15.0,8.5)\end{array}$ & $6.16, \mathrm{~s}$ & $\begin{array}{l}\text { 3.12, dd }(15.0,8.0) \\
2.88, \mathrm{dd}(15.0,8.5)\end{array}$ & $\begin{array}{l}3.09, \mathrm{dd}(15.0,8.5) \\
2.87, \mathrm{dd}(15.0,8.5)\end{array}$ \\
\hline 4 & $6.67, \mathrm{~s}$ & $6.87, \mathrm{~s}$ & $6.82, \mathrm{~s}$ & $6.74, d(8.0)$ & $6.58, d(8.0)$ \\
\hline 5 & - & - & - & $6.38, d(8.0)$ & $6.36, d(8.0)$ \\
\hline 7 & - & $6.39, \mathrm{~s}$ & $6.83, \mathrm{~s}$ & - & - \\
\hline $2^{\prime}$ & $7.19, d(8.5)$ & - & $7.10, d(8.5)$ & $7.18, d(8.5)$ & $7.17, d(8.5)$ \\
\hline $3^{\prime}$ & $6.86, d(8.5)$ & $6.48, d(2.5)$ & $6.74, d(8.5)$ & $6.85, d(8.5)$ & $6.85, d(8.5)$ \\
\hline $5^{\prime}$ & $6.86, d(8.5)$ & $6.43, \mathrm{dd}(8.0,2.5)$ & $6.74, d(8.5)$ & $6.85, d(8.5)$ & $6.85, d(8.5)$ \\
\hline $6^{\prime}$ & $7.19, d(8.5)$ & $6.98, d(8.0)$ & $7.10, d(8.5)$ & $7.18, d(8.5)$ & $7.17, d(8.5)$ \\
\hline $7^{\prime}$ & $\begin{array}{l}3.02, \mathrm{dd}(14.0,7.0) \\
2.84, \mathrm{dd}(14.0,6.5)\end{array}$ & $\begin{array}{l}\text { 3.07, dd }(15.0,3.5) \\
\text { 3.01, dd }(15.0,7.0)\end{array}$ & $3.91, \mathrm{~s}$ & $\begin{array}{l}\text { 3.16, dd }(14.0,6.0) \\
2.90, \mathrm{dd}(14.0,6.0)\end{array}$ & $\begin{array}{l}3.13, \mathrm{dd}(14.0,6.0) \\
2.90, \mathrm{dd}(14.0,6.0)\end{array}$ \\
\hline 5-Me & $2.12, \mathrm{~s}$ & $2.10, \mathrm{~s}$ & - & - & - \\
\hline 7-Me & $2.05, \mathrm{~s}$ & - & - & - & - \\
\hline 4'-OMe & $3.78, \mathrm{~s}$ & $3.75, \mathrm{~s}$ & - & $3.79, \mathrm{~s}$ & $3.78, \mathrm{~s}$ \\
\hline 6-OMe & - & $3.76,5$ & - & $3.82, \mathrm{~s}$ & - \\
\hline 7-OMe & - & - & - & $3.93, \mathrm{~s}$ & - \\
\hline$-\mathrm{OCH}_{2} \mathrm{O}-$ & - & - & - & - & $5.90, \mathrm{~s}$ \\
\hline
\end{tabular}

Table $2{ }^{13} \mathrm{C}$ NMR data of compounds 1-5

\begin{tabular}{|c|c|c|c|c|c|}
\hline Position & $1\left(C_{3} \mathrm{OD}\right)$ & $2\left(\mathrm{CDCl}_{3}\right)$ & $3\left(C_{3} \mathrm{OD}\right)$ & $4\left(\mathrm{CDCl}_{3}\right)$ & $5\left(\mathrm{CDCl}_{3}\right)$ \\
\hline 2 & 85.1 & 85.8 & 158.3 & 85.3 & 86.2 \\
\hline 3 & 35.9 & 34.0 & 103.5 & 34.3 & 34.5 \\
\hline $3 a$ & 118.0 & 117.2 & 122.0 & 121.2 & 122.9 \\
\hline 4 & 123.9 & 126.2 & 106.0 & 118.3 & 116.8 \\
\hline 5 & 117.3 & 119.0 & 143.1 & 109.9 & 104.3 \\
\hline 6 & 153.8 & 157.8 & 144.3 & 152.1 & 148.7 \\
\hline 7 & 108.1 & 93.6 & 98.6 & 133.7 & 130.0 \\
\hline $7 a$ & 158.1 & 157.2 & 150.7 & 151.4 & 141.9 \\
\hline $1^{\prime}$ & 131.2 & 116.2 & 130.1 & 129.3 & 129.1 \\
\hline $2^{\prime}$ & 131.4 & 156.2 & 130.8 & 130.4 & 130.3 \\
\hline $3^{\prime}$ & 114.7 & 102.9 & 116.2 & 113.9 & 113.9 \\
\hline $4^{\prime}$ & 159.8 & 160.2 & 157.0 & 158.4 & 158.3 \\
\hline $5^{\prime}$ & 114.8 & 106.4 & 116.2 & 113.9 & 113.9 \\
\hline $6^{\prime}$ & 131.4 & 132.1 & 130.8 & 130.4 & 130.3 \\
\hline $7^{\prime}$ & 42.0 & 36.9 & 34.8 & 40.9 & 40.7 \\
\hline 5-Me & 16.5 & 15.8 & - & - & - \\
\hline 7-Me & 9.2 & - & - & - & - \\
\hline 4'-OMe & 55.7 & 55.6 & - & 55.3 & 55.2 \\
\hline 6-OMe & - & 55.3 & - & 56.4 & - \\
\hline 7-OMe & - & - & - & 60.5 & - \\
\hline$-\mathrm{OCH}_{2} \mathrm{O}-$ & - & - & - & - & 100.2 \\
\hline
\end{tabular}

a test of the optical rotation, this compound was optically inactive. Therefore, the structure of compound $\mathbf{2}$ was determined to be 2-(2-hydroxyl-4-methoxy-benzyl)5-methyl-6-methoxyl-2,3-dihydrobenzofuran.

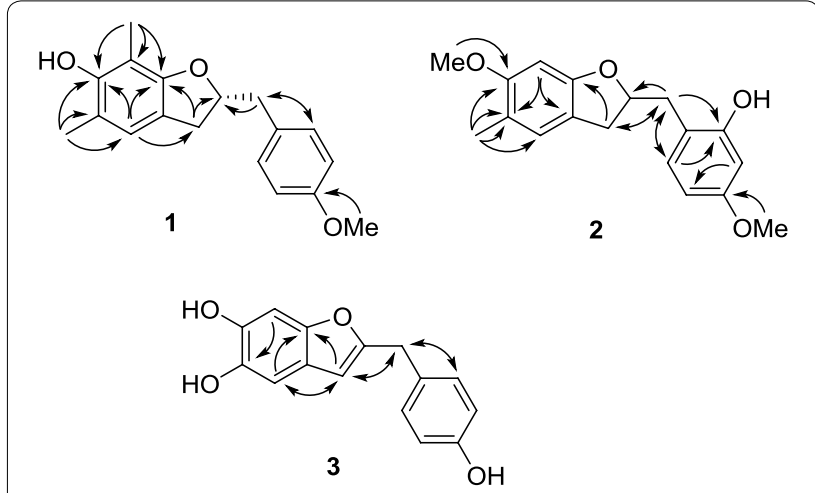

Fig. 2 Key HMBC correlations of 1-3

Compound 3 was obtained as a brown solid. Its HRESIMS revealed a molecular ion peak at $m / z 255.0632$ $[\mathrm{M}-\mathrm{H}]^{-}$corresponding to a molecular formula of $\mathrm{C}_{15} \mathrm{H}_{12} \mathrm{O}_{4}$. The ${ }^{1} \mathrm{H}$ NMR spectrum showed signals due to an olefinic proton $\left[\delta_{\mathrm{H}} 6.16(1 \mathrm{H}, \mathrm{s})\right]$, two aromatic protons $\left[\delta_{\mathrm{H}} 6.82(1 \mathrm{H}, \mathrm{s})\right.$, and $\left.6.83(1 \mathrm{H}, \mathrm{s})\right]$, a 1,4-disubstituted benzene ring with two apparent doublets $\left[\delta_{\mathrm{H}} 7.10(2 \mathrm{H}\right.$, $\mathrm{d}, J=8.5 \mathrm{~Hz}), 6.74(2 \mathrm{H}, \mathrm{d}, J=8.5 \mathrm{~Hz})]$, and a methylene group $\left[\delta_{\mathrm{H}} 3.91(2 \mathrm{H}, \mathrm{s})\right]$. The ${ }^{13} \mathrm{C}$ NMR and DEPT experiments showed one methylene, seven methines, five oxygenated aromatic carbons, and two quaternary carbons. In the $\mathrm{HMBC}$ spectrum, the correlations between the olefinic proton $\left(\delta_{\mathrm{H}} 6.16, \mathrm{H}-3\right)$ and $\mathrm{C}-3 \mathrm{a}\left(\delta_{\mathrm{C}} 122.0\right)$, $\mathrm{C}-4\left(\delta_{\mathrm{C}} 106.0\right)$, and $\mathrm{C}-7 \mathrm{a}\left(\delta_{\mathrm{C}} 150.7\right), \mathrm{H}-4 / \mathrm{C}-3\left(\delta_{\mathrm{C}} 103.5\right)$, 


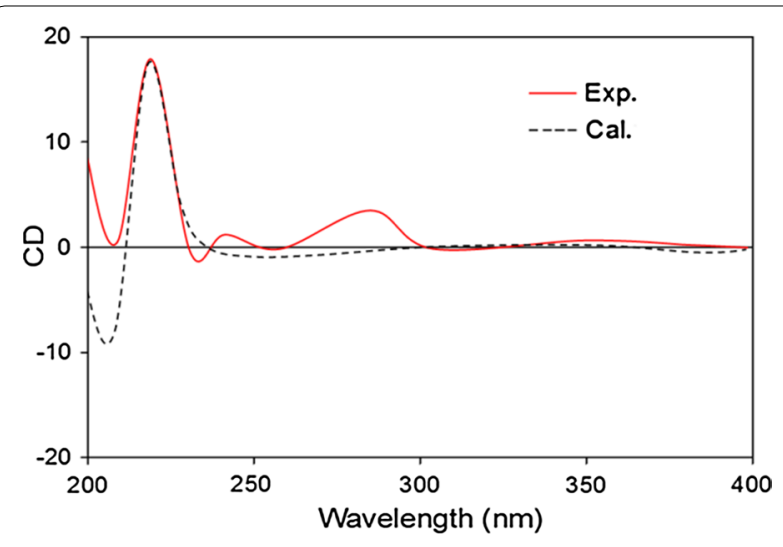

Fig. 3 Experimental and calculated CD spectrum for compound 1

C-3a, C-5 $\left(\delta_{C} 143.1\right), C-6\left(\delta_{C} 144.3\right)$, and C-7a, as well as $\mathrm{H}-7 / \mathrm{C}-3 \mathrm{a}, \mathrm{C}-5, \mathrm{C}-6$, and $\mathrm{C}-7 \mathrm{a}$ indicated the presence of a benzofuran skeleton with two oxygen substituents on ring A (Fig. 2). Similarly, the correlations between the 1,4-disubstituted protons $\left(\delta_{\mathrm{H}} 7.10, \mathrm{H}-2^{\prime}, 6^{\prime}\right)$ and the oxygenated aromatic carbon $\left(\delta_{\mathrm{C}} 157.0\right)$ and the methylene carbon $\left(\delta_{\mathrm{C}} 34.8\right)$ indicated the presence of a 4-hydroxybenzyl group. Moreover, the HMBC correlations of the methylene protons $\left(\delta_{\mathrm{H}} 3.19, \mathrm{H}-7^{\prime}\right)$ with $\mathrm{C}-2, \mathrm{C}-3$, and $\mathrm{C}-4$ suggested the location of the 4-hydroxy-benzyl group at C-2 (Additional file 1). This compound was also optically inactive. Therefore, the structure of $\mathbf{3}$ was assigned as 2-(4-hydroxy-benzyl)-5,6-dihydroxybenzofuran.

Compounds 4 and $\mathbf{5}$ were identified as 2-(4-methoxybenzyl)-6,7-dimethoxyl-2,3-dihydrobenzofuran, and 2-(4-methoxy-benzyl)-6,7-methylenedioxy-2,3-dihydrobenzofuran, respectively [12]. Both compounds were isolated for the first time from the nature. It is noted that the class of 2-benzyl-2,3-dihydrobenzofuran is uncommon and only a few compounds of this type have been isolated so far from natural source [15].

The isolated compounds were tested for their ability to inhibit NO production in LPS-stimulated RAW264.7 cells. NO is an important signalling molecule in various physiological and pathophysiological responses, including the circulation, blood pressure, platelet function, and host defence. The overproduction of NO is also important in inflammation and related processes [16]. High NO levels are used as a marker for the treatment of inflammatory disorders. According to its specific functions and characteristics, inhibition of NO production by immune cells, typically macrophages, is suggested as one strategy for the development of antiinflammatory agents. Our test revealed that compounds $\mathbf{1}$ and $\mathbf{2}$ reduced NO levels in LPS-stimulated RAW264.7 cells. Compound $\mathbf{1}$ was the most active compound with an $\mathrm{IC}_{50}$ of $11.4 \mu \mathrm{M}$, while compound 2 had a moderate effect $\left(\mathrm{IC}_{50}=29.1 \mu \mathrm{M}\right)$. Compounds $\mathbf{3}-\mathbf{5}$ were inactive up to the highest concentration tested $(30 \mu \mathrm{M})$. The cell viability test showed that neither compound had significant toxicity at its effective dose for NO inhibition (data not shown). 2,3-Dihydrobenzofurans have been known as potent anti-inflammatory compounds. Closse et al. [17] demonstrated that the synthetic analogues of 2,3-dihydrobenzofuran-2-one had powerful anti-inflammatory activity in vivo, and 5-chloro-6-cyclohexyl-2,3-dihydrobenzofuran-2-one was significantly more potent than the reference compound, diclofenac, in all testing models. More recently, a series of dihydrobenzofurans was isolated from the seeds of Prunus tomentosa, some of which strongly inhibited NO production in LPS-stimulated BV-2 cells [18]. Consistently, our results suggest that $O$. japonicus is a potential natural source of antiinflammatory dihydrobenzofurans.

\section{Methods}

\section{General experimental procedures}

Optical rotation values were recorded on a JASCO P-2000 digital polarimeter (JASCO, Tokyo, Japan). The IR spectra were obtained from a Tensor 37 FT-IR spectrometer (Bruker, Ettlingen, Germany). CD spectra were obtained with a JASCO J-1100 spectropolarimeter. NMR experiments were carried out on a Bruker AM500 FT-NMR spectrometer (Bruker, Rheinstetten, Germany) using residual solvent peak as a reference or tetramethylsilane (TMS) as internal standard. The HR-ESI-MS were recorded on a Waters Q-TOF micromass spectrometer Waters Q-TOF micromass spectrometer and an LTQ Orbitrap $\mathrm{XL}^{\mathrm{TM}}$ Mass spectrometer. Absorbance of bioassay solutions was read on an xMark microplate spectrophotometer.

\section{Plant materials}

The tubers of O. japonicus were collected in Feb. 2014 at Me Linh, Hanoi and identified by Prof. Tran Huy Thai, Institute of Ecology and Biological Resources, Vietnam Academy of Science and Technology. The voucher specimens were deposited at the Department of Bioactive Products, Institute of Marine Biochemistry, Vietnam Academy of Science and Technology.

\section{Extraction and isolation}

The air-dried and powdered tubers of O. japonicus $(2.4 \mathrm{~kg})$ were extracted with methanol $(4 \mathrm{~L} \times 3$ times $)$ in a sonic bath for $30 \mathrm{~min}$ at $40{ }^{\circ} \mathrm{C}$. The combined extracts were concentrated under a vacuum to obtain a crude residue $(360 \mathrm{~g})$, which was then resuspended in water $(2 \mathrm{~L})$, and extracted by chloroform ( $1 \mathrm{~L} \times 3$ times) to obtain chloroform $(8 \mathrm{~g})$ and water residues. The chloroform residue was chromatographed on a silica gel column eluted with a gradient of $1-100 \%$ ethyl acetate in hexane 
to afford nine fractions F1-F9. Fraction F1 was fractionated on a silica gel column eluted with hexane-ethyl acetate $(20: 1 \mathrm{v} / \mathrm{v})$ to give nine subfractions F1.1-F1.9. Compound 5 (69.5 mg) was purified from F1.4 by using a reverse phase $\mathrm{C}_{18}$ column eluted with acetone-water $(2: 1 \mathrm{v} / \mathrm{v})$. Compound $1(70.0 \mathrm{mg})$ and $4(18.2 \mathrm{mg})$ were isolated from F1.7 by using a reverse phase $\mathrm{C}_{18}$ column eluted with acetone-water $(3: 2 \mathrm{v} / \mathrm{v})$. The F1.9 was chromatographed on a silica gel column (hexane-acetone 8:1, $\mathrm{v} / \mathrm{v})$ to afford $2(20.8 \mathrm{mg})$. Compound $3(20.0 \mathrm{mg})$ was obtained from $\mathrm{F} 9$ by repeated $\mathrm{C}_{18}$ column (methanolwater $1: 1 \mathrm{v} / \mathrm{v}$ ) and silica gel column (dichloromethaneacetone $6: 1, \mathrm{v} / \mathrm{v})$.

\section{(2R)-(4-methoxybenzyl)-5,7-dimethyl-6-}

\section{hydroxyl-2,3-dihydrobenzofuran (1)}

Brown solid. $[\alpha]_{\mathrm{D}}^{24}=+86.5(c 0.05, \mathrm{MeOH})$. IR $(\mathrm{KBr})$ : 3446, 1615, 1513, 1472, 1247, 1097. CD (MeOH): 220 $(+17.8), 288(+3.2) .{ }^{1} \mathrm{H}-\left(\mathrm{CD}_{3} \mathrm{OD}, 500 \mathrm{MHz}\right)$ and ${ }^{13} \mathrm{C}-$ NMR ( $\left.\mathrm{CD}_{3} \mathrm{OD}, 125 \mathrm{MHz}\right)$ : see the Tables 1 and 2. HRESI-MS (neg.): $283.1365[\mathrm{M}-\mathrm{H}]^{-}$(calc. for $\mathrm{C}_{18} \mathrm{H}_{19} \mathrm{O}_{3}$, 283.1334).

\section{2-(2-Hydroxyl-4-methoxy-benzyl)-5-methyl- 6-methoxyl-2,3-dihydrobenzofuran (2)}

Brown solid. IR (KBr): 3440, 1610, 1482, 1245, 1120. ${ }^{1} \mathrm{H}-\left(\mathrm{CDCl}_{3}, 500 \mathrm{MHz}\right)$ and ${ }^{13} \mathrm{C}-\mathrm{NMR}\left(\mathrm{CDCl}_{3}, 125 \mathrm{MHz}\right)$ : see the Tables 1 and 2. HR-ESI-MS (pos.): 301.1436 $[\mathrm{M}+\mathrm{H}]^{+}$(calc. for $\mathrm{C}_{18} \mathrm{H}_{21} \mathrm{O}_{4}, 301.1440$ ).

\section{2-(4-Hydroxy-benzyl)-5,6-dihydroxybenzofuran (3)}

Brown solid. IR (KBr): 3450, 1613, 1514, 1484, 1242, 1142. ${ }^{1} \mathrm{H}-\left(\mathrm{CD}_{3} \mathrm{OD}, 500 \mathrm{MHz}\right)$ and ${ }^{13} \mathrm{C}-\mathrm{NMR}\left(\mathrm{CD}_{3} \mathrm{OD}\right.$, $125 \mathrm{MHz}$ ): see the Tables 1 and 2. HR-ESI-MS (neg.): $255.0632[\mathrm{M}-\mathrm{H}]^{-}$(calc. for $\mathrm{C}_{15} \mathrm{H}_{11} \mathrm{O}_{4}, 255.0657$ ).

\section{Assay for inhibition of NO production}

The effects of compounds on the NO production in LPS-stimulated RAW264.7 cells were evaluated as previously described [19]. The cells were seeded in 96-well plate at $2 \times 10^{5}$ cells/well and incubated for $12 \mathrm{~h}$. The plate were pretreated with compounds in various concentrations (from 1 to $30 \mu \mathrm{M}$ ) for $30 \mathrm{~min}$ and then incubated for another $24 \mathrm{~h}$ with or without $1 \mu \mathrm{g} / \mathrm{ml}$ LPS. $100 \mu \mathrm{l}$ of the culture supernatant were transferred to other 96-well plate and $100 \mu \mathrm{l}$ of Griess reagent were added. The absorbance of the reaction solution was read at $570 \mathrm{~nm}$ with a microplate reader (XMark microplate reader, Biorad, USA). The remaining cell solutions in cultured 96-well plate were used to evaluate cell viability by 3-(4,5-dimethylthiazole-2-yl)-2,5-diphenyl tetrazolium bromide (MTT) assay. Cardamonin was used as a positive control $\left(\mathrm{IC}_{50}=2.80 \mu \mathrm{M}\right)$.

\section{Conclusion}

In summary, three 2-benzyl-2,3-dihydrobenzofurans and two 2-benzyl-benzofurans were isolated from the $\mathrm{CHCl}_{3}$-soluble fraction of the $\mathrm{MeOH}$ extract of $O$. japonicus tubers. Their structures were found to be (2R)-(4-methoxybenzyl)-5,7-dimethyl-6-hydroxyl-2,3-dihydrobenzofuran (1), 2-(2-hydroxyl4-methoxy-benzyl)-5-methyl-6-methoxyl-2,3-dihydrobenzofuran (2), 2-(4-hydroxy-benzyl)-5,6-dihydroxybenzofuran (3), 2-(4-methoxy-benzyl)-6,7-dimethoxyl-2,3-dihydrobenzofuran (4), and 2-(4-methoxy-benzyl)-6,7-methylenedioxy2,3-dihydrobenzofuran (5). Compounds 1 and 2 inhibited NO production in LPS-stimulated RAW264.7 cells.

\section{Additional file}

Additional file 1. NMR spectra of compounds 1-3

\section{Authors' contributions}

NHD and NTD designed research and wrote the paper; NDC, HMT and NVT performed research; NTH and DL analyzed CD data. All authors read and approved the final manuscript.

\section{Author details \\ ${ }^{1}$ Advanced Center for Bio-organic Chemistry, Institute of Marine Biochemistry, Vietnam Academy of Science and Technology (VAST), 18-Hoang Quoc Viet, Cau Giay, Hanoi, Vietnam. ${ }^{2}$ Institute of Marine Biochemistry, Vietnam Academy of Science and Technology (VAST), 18-Hoang Quoc Viet, Cau Giay, Hanoi, Vietnam. ${ }^{3}$ Graduate University of Science and Technology, Vietnam Academy of Science and Technology (VAST), 18-Hoang Quoc Viet, Cau Giay, Hanoi, Vietnam. ${ }^{4}$ National Institute of Medicinal Materials, 1B Quang Trung, Hoan Kiem, Hanoi, Vietnam. ${ }^{5}$ Department of Biosystems and Biotechnology, College of Life Sciences and Biotechnology, Korea University, Seoul 02841, Republic of Korea.}

\section{Acknowledgements}

This work is supported by the National Foundation for Science and Technology Development (NAFOSTED 104.01-2014.05). We thank the Institute of Chemistry (VAST) for the NMR experiments.

\section{Competing interests}

The authors declare that they have no competing interests.

Received: 24 October 2016 Accepted: 20 January 2017

Published online: 06 February 2017

\section{References}

1. Do TL (2004) Vietnamese medicinal herbs and remedies. Medicinal Publisher, Hanoi

2. Qi J, Hu ZF, Zhou YF, Hu YJ, Yu BY (2015) Steroidal sapogenins and glycosides from the fibrous roots of Ophiopogon japonicus and Liriope spicata var. prolifera with anti-inflammatory activity. Chem Pharm Bull 63:187-194

3. Ye Y, Qu Y, Tang R, Cao S, Yang W, Xiang L, Qi J (2013) Three new neuritogenic steroidal saponins from Ophiopogon japonicus (Thunb.) Ker-Gawl. Steroids 78:1171-1716

4. Chen MH, Chen XJ, Wang M, Lin LG, Wang YT (2016) Ophiopogon japonicus - a phytochemical, ethnomedicinal and pharmacological review. J Ethnopharmacol 181:193-213

5. Duan CL, Kang ZY, Lin CR, Jiang Y, Liu JX, Tu PF (2009) Two new homoisoflavonoids from the fibrous roots of Ophiopogon japonicus (Thunb.) Ker-Gawl. J Asian Nat Prod Res 11:876-879 
6. Hung TM, Thu CV, Dat NT, Ryoo SW, Lee JH, Kim JC, Na M, Jung HJ, Bae K Min BS (2010) Homoisoflavonoid derivatives from the roots of Ophiopogon japonicus and their in vitro anti-inflammation activity. Bioorg Med Chem Lett 20:2412-2416

7. Fan Y, Ma X, Zhang J, Ma L, Gao Y, Zhang W, Song X, Hou W, Guo C, Tong D (2015) Ophiopogon polysaccharide liposome can enhance the nonspecific and specific immune response in chickens. Carbohydr Polym 119:219-227

8. Lin Y, Zhu D, Qi J, Qin M, Yu B (2010) Characterization of homoisoflavonoids in different cultivation regions of Ophiopogon japonicus and related antioxidant activity. J Pharm Biomed Anal 52:757-762

9. Cheng ZH, Wu T, Bligh SW, Bashall A, Yu BY (2004) cis-Eudesmane sesquiterpene glycosides from Liriope muscari and Ophiopogon japonicus. J Nat Prod 67:1761-1763

10. Liu C, Ju A, Zhou D, Li D, Kou J, Yu B, Qi J (2016) Simultaneous qualitative and quantitative analysis of multiple chemical constituents in YiQiFuMai injection by ultra-fast liquid chromatography coupled with ion trap timeof-flight mass spectrometry. Molecules 21:E640

11. Luiking YC, Engelen MP, Deutz NE (2010) Regulation of nitric oxide production in health and disease. Curr Opin Clin Nutr Metab Care 13:97-104

12. Qi P, Jiang J, Qi H, Jin Y, Shen Q, Wu Y, Song H, Zhang W (2013) Synthesis and antiproliferative activity of new polyoxo 2-benzyl-2,3-dihydrobenzofurans and their related compounds. Lett Drug Des Discov 10:886-894
13. Ortega N, Urban S, Beiring B, Glorius F (2012) Ruthenium NHC catalyzed highly asymmetric hydrogenation of benzofurans. Angew Chem Int Ed $51: 1710-1713$

14. Kwon J, Hiep NT, Kim DW, Hong S, Guo Y, Hwang BY, Lee HJ, Mar W, Lee D (2016) Chemical constituents isolated from the root bark of Cudrania tricuspidata and their potential neuroprotective effects. J Nat Prod 79:1938-1951

15. Tsai YC, Hsu CC, El-Shazly M, Chiang SY, Wu CC, Wu CC, Lai WC, Yen MH, Wu YC, Chang FR (2015) Phytochemicals and estrogen-receptor agonists from the aerial parts of Liriope platyphylla. Molecules 20:6844-6855

16. Aktan $F(2004)$ iNOS-mediated nitric oxide production and its regulation. Life Sci 75:639-653

17. Closse A, Haefliger W, Hausser D, Gubler HU, Dewald B, Baggiolini M (1981) 2,3-Dihydrobenzofuran-2-ones: a new class of highly potent antiinflammatory agents. J Med Chem 24:1465-1471

18. Liu QB, Huang XX, Bai M, Chang XB, Yan XJ, Zhu T, Zhao W, Peng Y, Song SJ (2014) Antioxidant and anti-inflammatory active dihydrobenzofuran neolignans from the seeds of Prunus tomentosa. J Agri Food Chem 62:7796-7803

19. Dat NT, Binh PT, Quynh LTP, Huong HT, Minh CV (2012) Sanggenon C and $\mathrm{O}$ inhibit NO production, iNOS expression and NF-KB activation in LPSinduced RAW264.7 cells. Immunopharmacol Immunotoxicol 34:84-88

\section{Submit your manuscript to a SpringerOpen ${ }^{\circ}$ journal and benefit from:}

- Convenient online submission

- Rigorous peer review

- Immediate publication on acceptance

- Open access: articles freely available online

- High visibility within the field

- Retaining the copyright to your article 